Brief

Article

\title{
Iranian Journal of Medical Microbiology
}

Iran J Med Microbiol: Volume 13, Number 4 (September-October)

Journal homepage: www.ijmm.ir

\section{The Prevalence of CTX-M Beta-Lactamase Gene in Urinary Tract Infections in} Patients Referring to Bonab City Hospitals

\author{
Reza Mohammadzadeh $^{1 *[D,}$ Ali Mohammadi-Gollou' ${ }^{1}$, Yaser Salehabadi
}

1. Department of Biology, Faculty of Basic Sciences, University of Marahgheh, Maragheh, Iran

2. Department of Toxicology and Pharmacology, Faculty of Pharmacy, Mazandaran University of Medical Sciences, Sari, Iran

\section{Article Information}

\section{Article Subject:}

Molecular Epidemiology

dei 10.30699/ijmm.13.4.302

Corresponding author:

Reza Mohammadzadeh

Department of Biology, Faculty of Basic Sciences, University of

Marahgheh, Maragheh, Iran

Email:

rmohamadzadeh82@gmail.com

Use your device to scan and read the article online

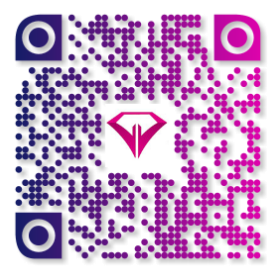

\section{Abstract}

Background and Aims: Urinary Tract Infection (UTI) is one of the most common bacterial infections, and several studies have reported the prevalence of UTI caused by ESBLproducing E.coli strains in different cities of Iran. The aim of this study was to evaluate antibiotic resistant UTI factors in outpatients and determine the prevalence of ctx-m gene in ESBL-producing E. coli strains of Bonab (East Azerbaijan, Iran).

Materials and Methods: In 2015, 266 clinical isolates of E. coli were collected from clinical laboratories in Bonab. Phenotypic screening and confirmation tests for extendedspectrum beta-lactamases (ESBLs) were carried out using disk diffusion (Kirby Bauer) method. All of the ESBL producing isolates were tested by PCR using specific primers. A total of 10 PCR products were randomly selected and purified and subsequently sent for sequencing.

Results \& Conclusion: The maximum resistance was seen regarding ampicillin (67.3\%) and the maximum sensitivity was seen regarding imipenem (92.5\%). In this study, $45 \%$ of isolates were multidrug resistance, which showed at least resistance for three antibiotics. Out of 154 isolates, $58(37.7 \%)$ isolates were ESBL producers which $94.8 \%$ of isolates contained $c t x-m$ gene. The prevalence of the $c t x-m$ gene, as in other parts of Iran and the world, is high in Bonab. For the treatment of infections suspected to be an ESBL producer, appropriate antibiotics should be selected, and strains that have decreased their sensitivity to ceftazidime, cefotaxime, and cefetoxin should be considered for ESBL genes.

Keywords: Escherichia coli, UTI, ESBLs, CTX-M

Received: 2019/06/25

Accepted: 2019/09/11

Available online: 2020/01/1

Copyright ( $) 2019$ Iranian Journal of Medical Microbiology. This is an open-access article distributed under the terms of the Creative Commons Attribution License (http://creativecommons.org/licenses/by/4.0), which permits unrestricted use, distribution, and reproduction in any medium, provided the original work is properly cited.

How to cite this article:

Mohammadzadeh R, Mohammadi-Gollou A, Salehabadi Y. The Prevalence of CTX-M BetaLactamase Gene in Urinary Tract Infections in patients referring to Bonab city Hospitals. Iran J Med Microbiol. 2019; 13 (4) :302-309

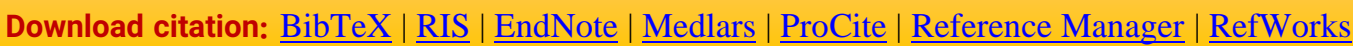
Send citation to: $8 \underline{\text { Mendeley }} \mathbf{Z}$ Zotero $(H) \underline{\text { RefWorks }}$ 


\section{Introduction}

Urinary Tract Infection (UTI) is one of the most common bacterial infections and the second most common infection in patients referred to hospitals (1). Given the role of Escherichia coli in the infection of the urethra, it is important to know the pattern of susceptibility of this bacterium to various antibiotics. The use of broad-spectrum antibiotics is widely used in the treatment of bacterial infections today, and this has led to antibiotic resistance in this group of bacteria $(2,3)$. The emergence of new antibiotics such as broad-spectrum cephalosporins and azetronam and their use in the treatment of bacterial infectious diseases has led to the expression of a new class of these enzymes called Extended Spectrum Blactamase (ESBL) (4).

Broad-spectrum antibiotics are transcribed by genes such as $c t x-m$, tem, shv and per. Due to the increasing number of different types of ESBL bla SHV, bla TEM (bla CTX-M) and their different effects on different antibiotics, accurate determination of different types of ESBL enzymes by molecular methods such as PCR is necessary to identify regional resistance. (5) Since there is no comprehensive research on this subject in Bonab city so far, in this study we investigated the drug resistance of ESBL-producing Escherichia coli strains and $c t x-m$ gene in urinary tract isolates obtained from patients referred. We studied hospitals in Bonab city of East Azerbaijan province.

\section{Materials and Methods}

A total of 266 positive urine cultures of $E$. coli from hospital labs were collected and studied in 2015. Criteria for data entry in this study were sample patient satisfaction and urine culture positive for $E$. coli and data exclusion criteria were patient dissatisfaction, urine culture positive for $E$. coli and recorded or incomplete data. Blood agar (Difco, USA) was used as a primary medium for bacterial detection by API kit (Biomerieux France) and antibiogram antibacterial test. After bacterial inoculation in eosin methylene blue agar medium (Merck, Germany), MR / VP medium (Oxoid, UK) and SIM agar medium (Merck, Germany) to investigate bacterial motility and molar Hinton broth medium (Merck, Germany) Bacteria were used for antibiotic testing as well as the Mulherton
Agar medium (Merck, Germany) for antibiotic testing.

Screening tests for selected strains resistant to selected cephalosporins and other antibiotics were performed by disk diffusion method and the diameter of bacterial growth halo was measured. Finally, using Rosco's CLSI tables, the bacteria were divided into three groups of susceptible, intermediate, and resistant, and the results of each isolate were recorded for all discs used. Antimicrobial susceptibility to amikacin and ciprofloxacin were also determined. Antimicrobial susceptibility testing of hybrid discs was performed for confirmation of broad-spectrum beta-lactamase producing strains by disk diffusion method.

E. coli strain (ATCC 25922) were used as a negative control for antibiogram tests and Klebsiella pneumoniae strain (ATCC 7881) were used as positive control.

DNA extraction from the samples was accomplished by boiling and their concentration was measured by spectroscopy and DNA concentration determination. DNA extraction from The ESBL positive strains were performed amplified by PCR executed using specific primers (Ctx -F: 5'TITGCGATGTGCAGTACCAG-3') and (Ctx -R: 5'GATATCGTTGGTGGTGCCAT-3') genes. Ctx-M was amplified and electrophoresis on agarose gel was used to evaluate the results of various experiments, including DNA extraction and PCR.

For statistical analysis of the relationship between the data obtained in different stages of this study, the data were entered into SPSS 21 (SPSS Inc., Chicago, III., USA) and the significance of the data was analyzed by Chi-square test.

\section{Results and Discussion}

A total of 266 specimens of suspected urine cultures of $E$. coli were collected from outpatients referred to hospitals. Bacterial isolates were cultured on eosin methylene blue agar medium, Triple Sugar Iron agar medium (TSI), Simon citrate agar, SIM and MR / VP. Acid-acidity in the TSI tube, citrate test negative, indole production, motility and $\mathrm{H} 2 \mathrm{~S}$ production were confirmed for culture.

According to the statistical analysis, $99.26 \%$ of the isolates were identified as E.coli and only two 
isolates were identified as Enterobacter and Serachia. The results of these kits indicate that in $99.26 \%$ of the cases the results are consistent with classical biochemical tests.

The isolates were evaluated for susceptibility to antibiotics ampicillin, ciprofloxacin, ceftraxation, imipim, amikacin, cefipim, azotrenam, cefotaxime and ceftazidime.

The maximum and minimum resistance for each of antibiotics were seen for ampicillin (67.3\%) and imipim (5.3\%) respectively. Also, the highest antibiotic susceptibility among the isolates was related to imipim (92.5\%). Also, $45 \%$ of strains isolated from $\mathrm{E}$. coli showed resistance to more than three antibiotics.

During the screening test out of 154 samples out of 264 confirmed E.coli, 112 were selected according to CLSI criteria and 42 others were selected according to resistance to different antibiotic groups. In the final test (combined disk), 58 E. coli strains (37.7\%) out of 154 strains were reported as ESBL producing bacteria. In addition, a total of 58 ESBL producers were selected in accordance with CLSI criteria.

The $c t x-m$ gene as one of the ESBL-producing genes was investigated in this study. Of the 264 Escherichia coli samples, 68 (25.5\%) had ctx-m gene, and of the $58 \mathrm{ESBL}$ positive, 55 (94.8\%) were $c t x-m$ positive. The $c t x-m$ gene had a $544 \mathrm{bp}$ region. It should be noted that in some isolates lacking ESBL, the $c t x-m$ gene was also identified (Figure 1).

Ampicillin resistance was very high (67.3\%) among the studied isolates, which was in agreement with the results of other studies in Iran and elsewhere in the world. The frequency of resistance of E.coli isolates to cefteriaxone, cefotaxime and ceftazidime were $50.8 \%, 48.5 \%$ and $30.5 \%$, respectively (6-8). The least antibiotic resistance was observed in imipenem (5.3\%) and the highest susceptibility was to this antibiotic. Consistent with the results of other studies in Iran and somewhere else in the world that reported high sensitivity (9-11).

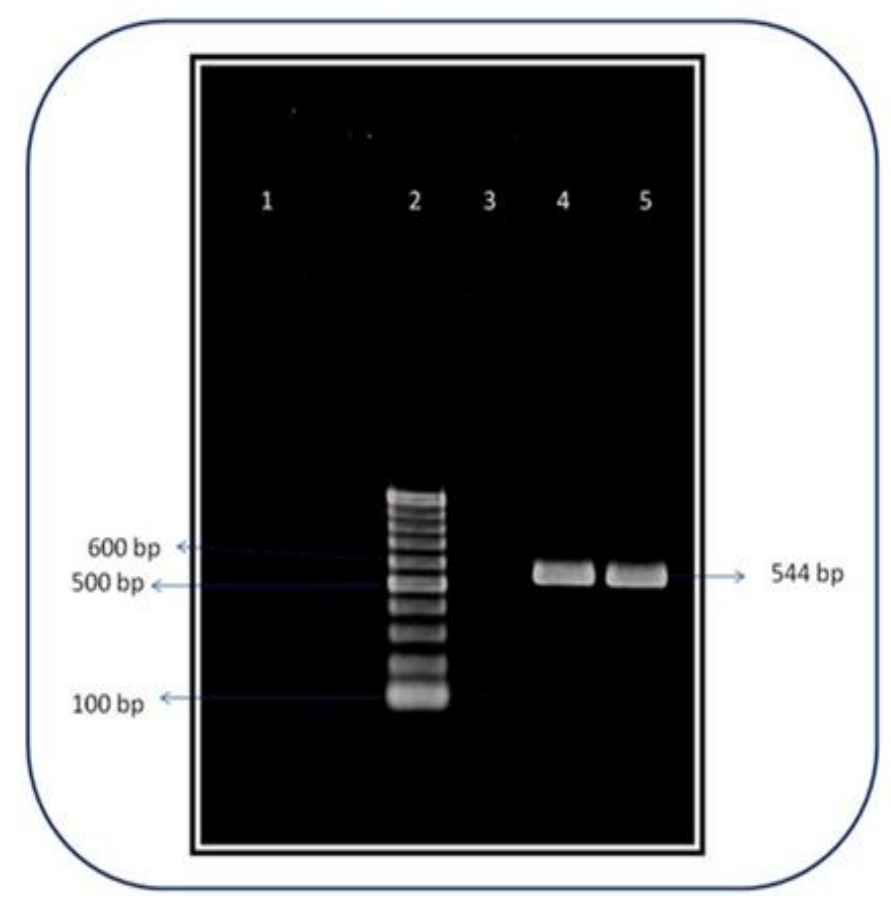

Figure 1. PCR product electrophoresis for the ctx-m gene. Lane 1: Blank, Lane 2: Marker (100bp DNA Ladder) Lane 3: Ctx-m negative control, Lane 4: Ctx-m positive control, Lane 5: PCR positive ctx-m gene. 
Different prevalence of $c t x-m$ gene in Iran and other countries can be due to cephalosporins and fluoroquinolones usage patterns in treatment of infections, transferability of $c t x-m$ gene from animal reservoirs such as poultry and pets to humans, international travel, observance of control standards Nosocomial infection, primary origin of ctx-m gene from Kluyvera, transmission and movement of plasmids carrying $c t x-m$ gene among different strains $(12,13)$.

The prevalence of the $c t x-m$ gene, as in other parts of Iran and the world, is high in Bonab. For the treatment of infections suspected to be an ESBL producer, appropriate antibiotics should be selected, and strains that have decreased their sensitivity to ceftazidime, cefotaxime, and cefetoxin should be considered for ESBL genes.

\section{Acknowledgments}

The authors would like to express their gratitude and appreciation to the staff of the Diagnostic Laboratories of Bonab city Hospitals and the University of Maragheh Microbiology Laboratory.

\section{Conflict of Interest}

The authors declared no conflict of Interest. 


$$
\begin{aligned}
& \text { مجله ميكروبشناسى يزشكى ايران }
\end{aligned}
$$

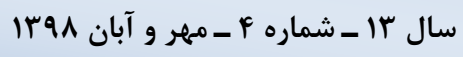

$$
\begin{aligned}
& \text { Journal homepage: www.ijmm.ir }
\end{aligned}
$$

\section{بررسى فراوانى ذن مقاومت بتالاكتاماز CTX-M در ايزولههاى عفونت ادرارى بيماران

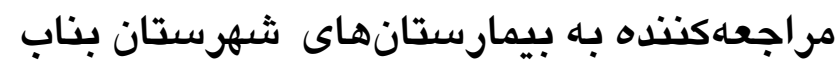

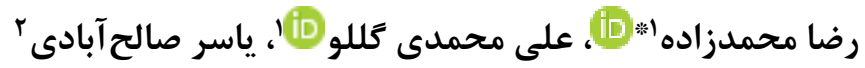

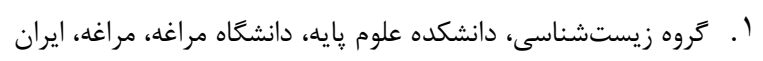

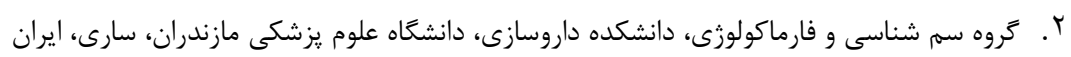

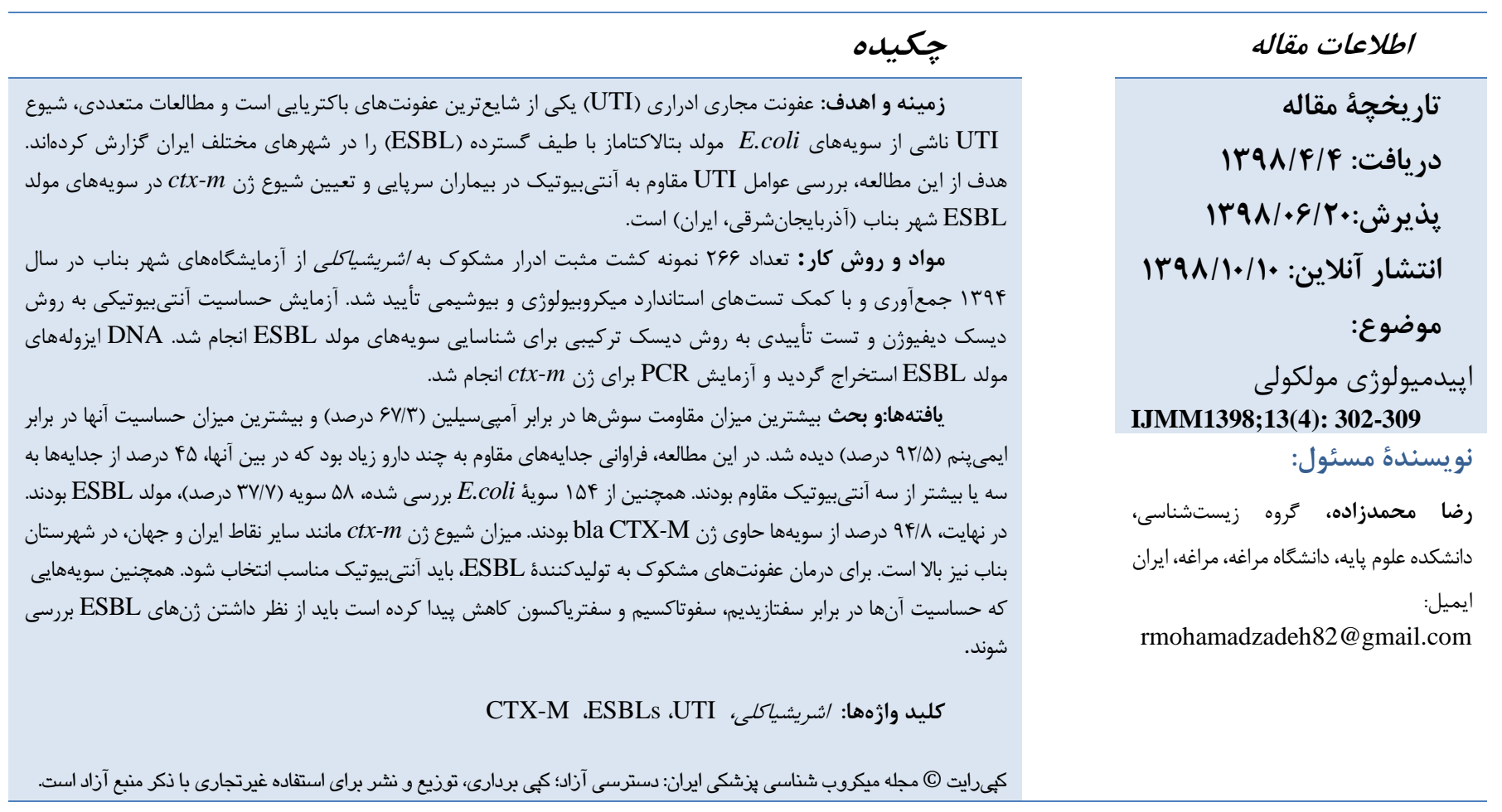

مقدمه

از اين آنزيمها، بتالاكتامازهاى وسيع الطيف Extended spectrum تعSBL) Blactamase

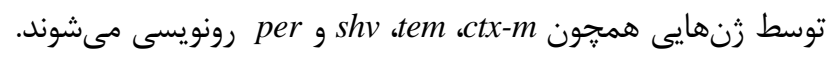

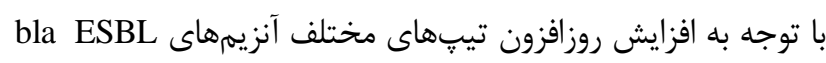
و و تأثير متفاوت آنها بر (bla CTX-M ،la TEM ،SHV) آنتىبيوتيكهاى مختلف، تعيين دقيق تيبهاى مختلف آنزيمهاى

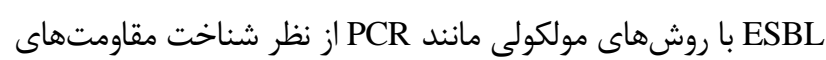

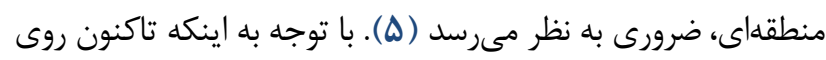

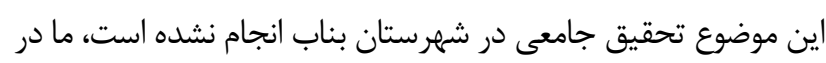

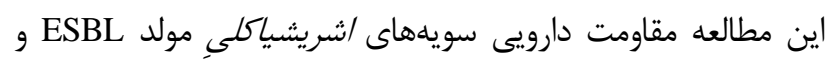

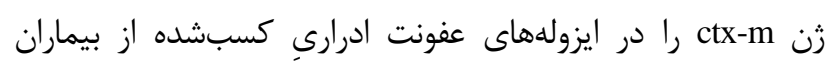

عفونت مجارى ادرارى (UTI) يكى از شايعترين عفونتهاى

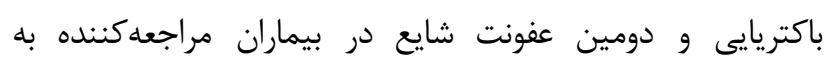

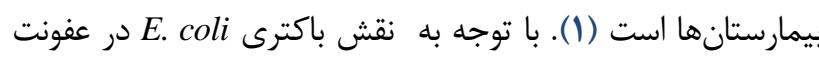

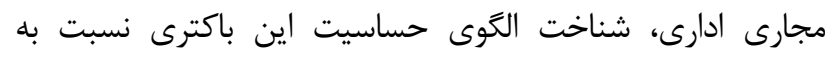

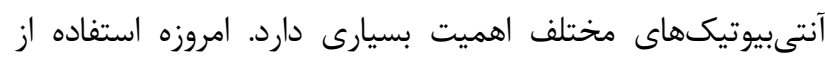

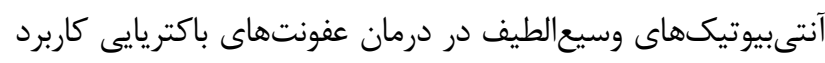

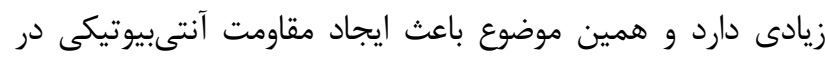

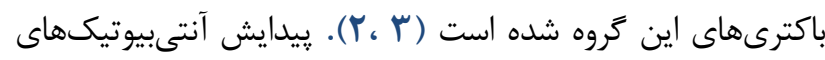

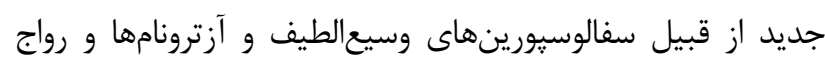

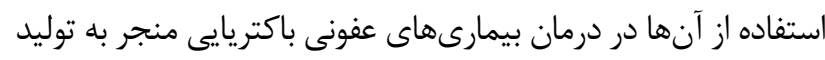

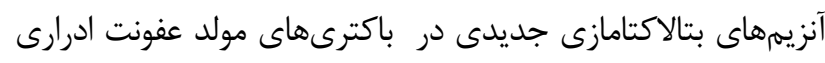

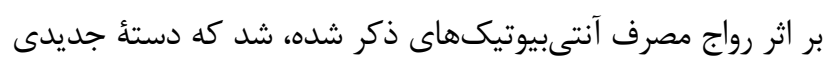


براساس استاندارد CLSI استفاده شد. در تستهاى آنتىبيوگرام

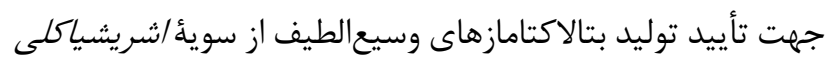

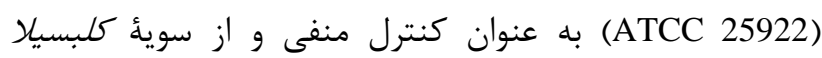
ينومونيه (ATCC 7881) به عنوان كنترل مثبت استفاده شد.

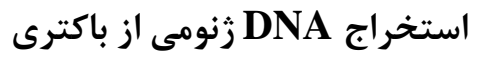

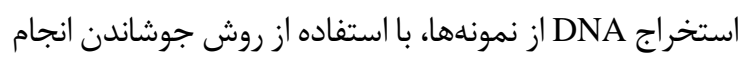

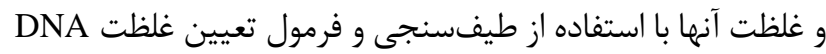

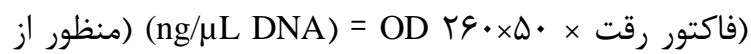

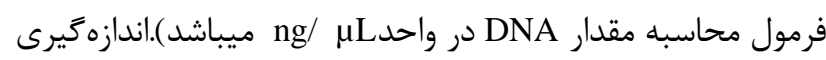
شد. سيس آزمايش ايزولههايى كه تست فنوتيبى توليد بتالاكتاماز

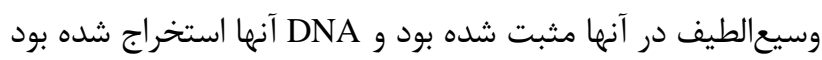

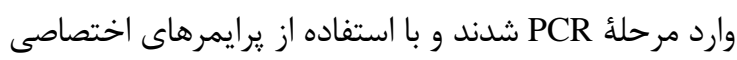
$C t x)$, (5'-TTTGCGATGTGCAGTACCAG-3': Ctx -F)

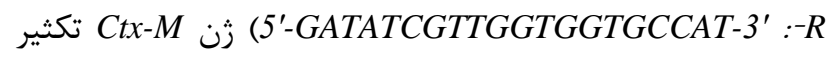
كرديد. براى بررسى نتيجه آزمايشات مختلف، از جمله استخراج PCR و DNA از الكتروفورز روى زل آكارز استفاده شد.

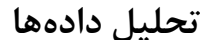

براى بررسى آماري وجود ارتباط بين دادههاى به دست دآدآ دآدهد

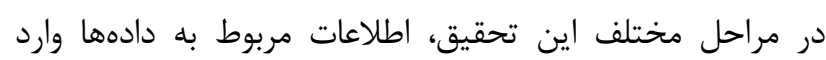
نرمافزار آمارى SPSS نسخة آلr SPSS Inc., Chicago, IL., USA)

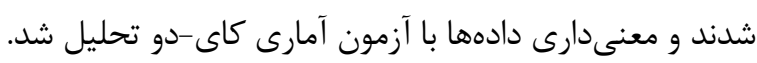
يافته ها و بحث

\section{E.coli تأييد نمونه}

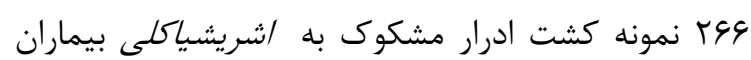

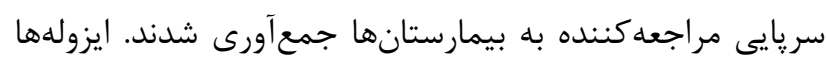

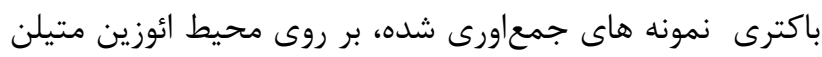

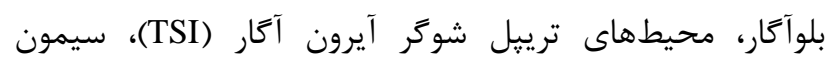

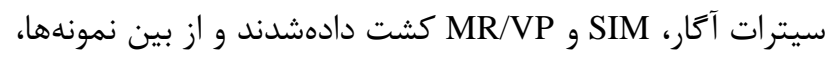

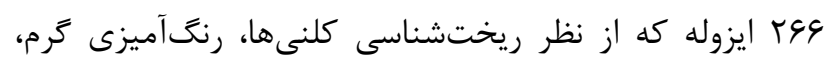

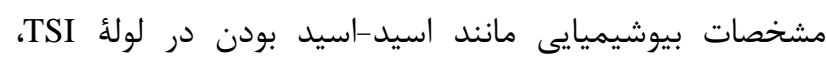

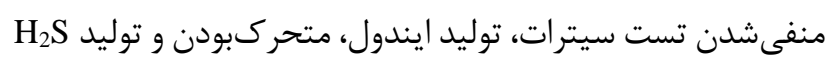

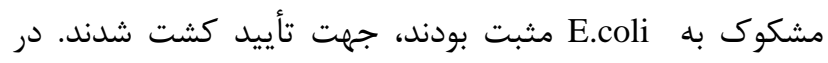

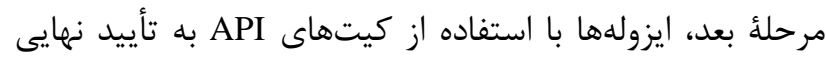

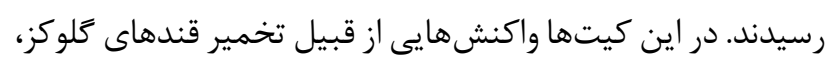
مانوز، اينوزيتول، سوربيتول، رامنوز، ساكارز، ملوبيوز، آميلوز

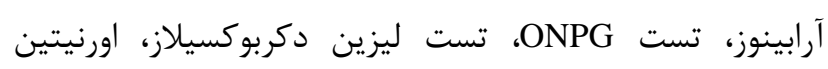

مراجعهكننده به بيمارستانهاى شهرستان بناب استان اذربايجان

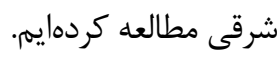
مواد و روش كار

\section{E.coli نمونه تيرى و جداسازى روس كار}

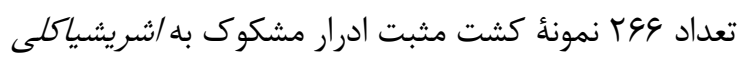
از آزمايشكاههاى شهرستان بناب به طور تصادفى ساده، در سال

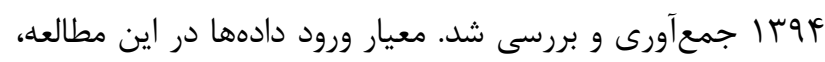

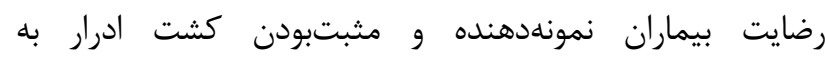

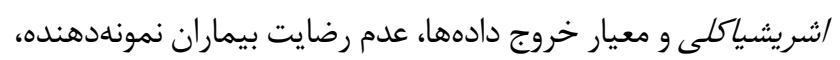

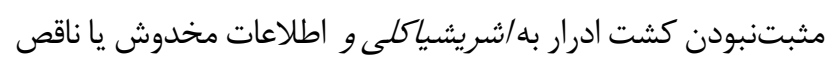

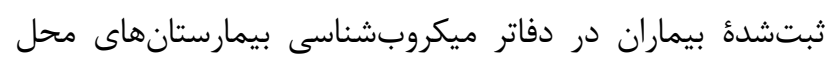

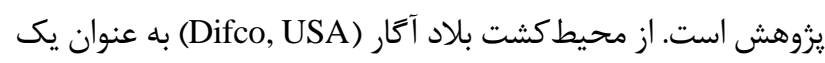

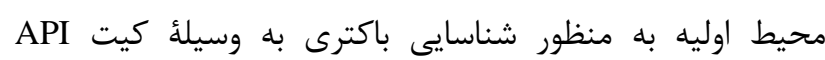
و و تست آنتى بيوگر ام باكترى استفاده كرديد.

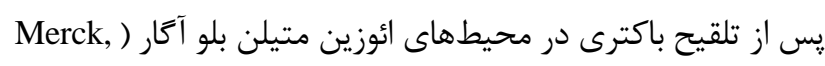

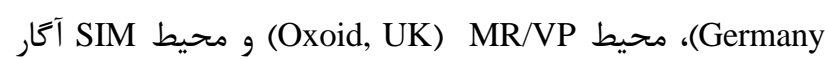
به منظور بررسى حركت باكترى، محيط مولر (Merck, Germany)

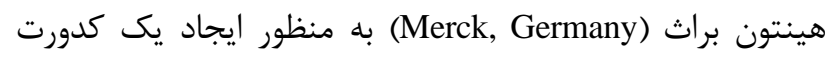

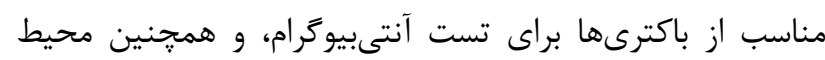

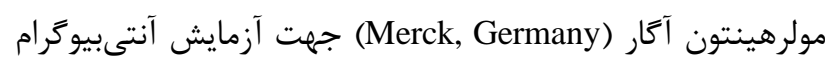

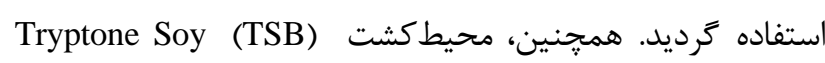
Merck, (Merck, Germany) Broth Merck, ) (TSI) و محيط ترييل شوكر آيرون آكار (Germany (Germany

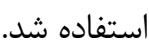

\section{تست غربالكرى سويه هاى مقاوم}

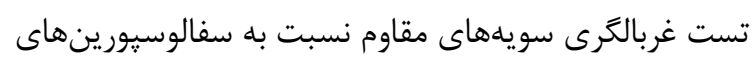

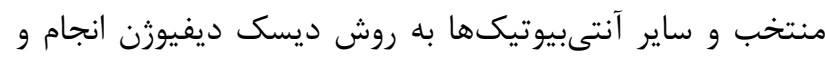

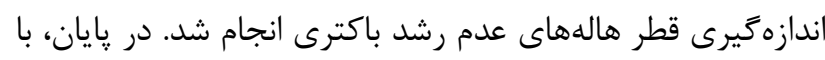

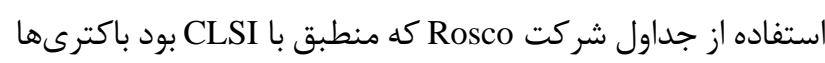
به سه كروه حساس، حساسيت متوسط و مقاوم تقسيم شدند. نتايج

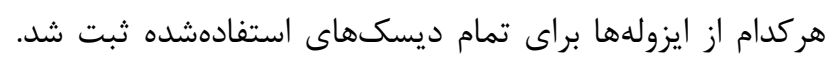

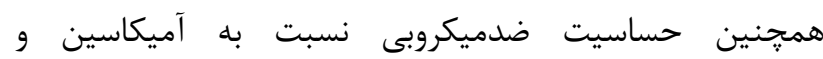

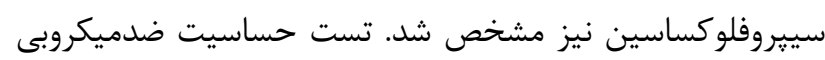
نسبت به ديسك هاى تركيبى براى تأييد سويههاى مولد بتالاكتاماز

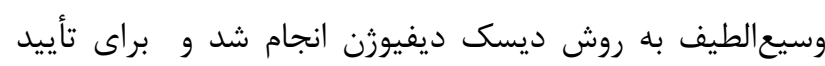

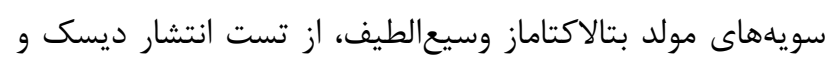




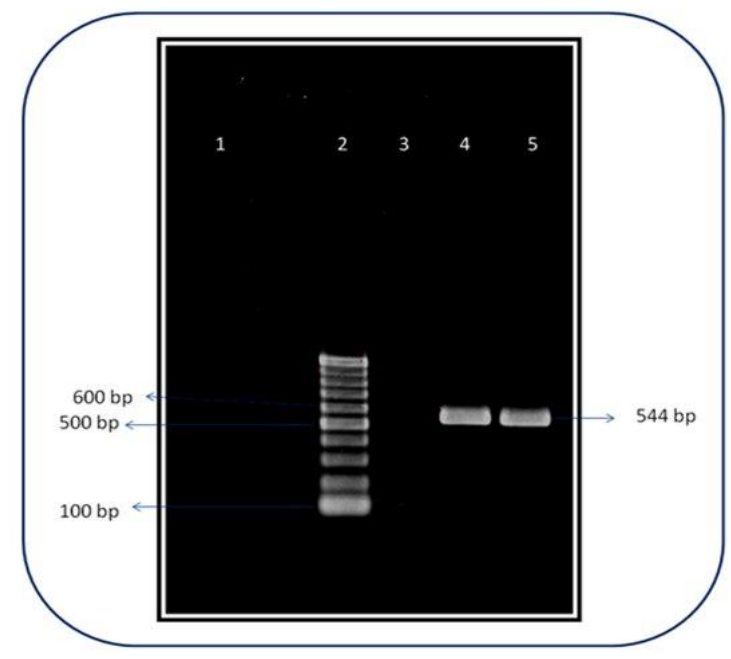

شكل ا. الكتروفورز محصول PCR براى زن PAR-m بلانك؛ رديف ז: ماركر (100bp DNA Ladder)؛ رديف זّ: كنترل

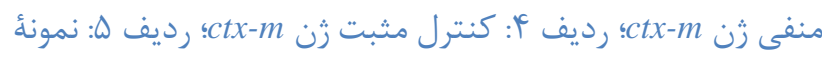
ctx-m مثبت زن رن مCR

در بين جدايههاى موردبررسى، مقاومت به آميى سيلين بسيار

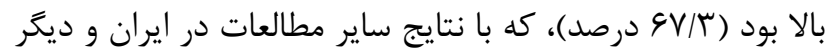

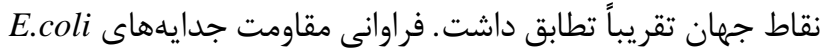

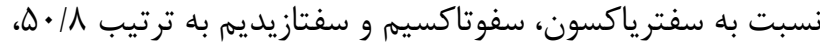

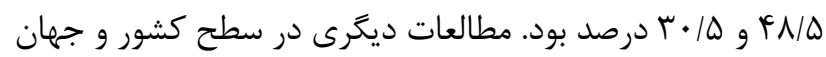
افزايش فراوانى مقاومت به جدايههاى E. coli أتأييد مى كنند

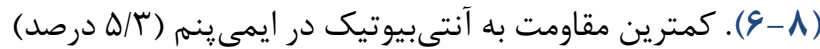
و بيشترين حساسيت نيز مربوط به اين آنتىبيوتيك بود كه با نتايج ساير مطالعات در ايران و ساير نقاط جهان كه ميزان حساسيت إنتين بالايى را گزارش كرده بودند تطابق داشت (11-9). آمارهاى متفاوت شيوع رن ctx-m در ايران و ساير كشورهاى دنيا مىتواند ناشى از الكوى مصرف سفالوسيورينها و فلورو -

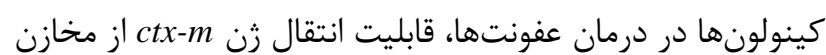
حيوانى مثل ماكيان و حيوانات اهلى به انسان، مسافرتهاى بينالمللى، رعايت استانداردهاى كنترل عفونت بيمارستانى، منشأ

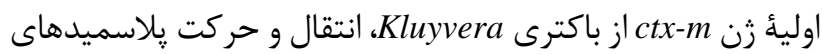

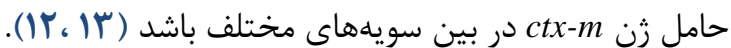

توليد ESBL تهديدى بزرگ براى مصرف سفالوسيورين باطيف وسيع به شمار مىرود. بنابراين براى درمان عفونتهايى كه مشكوكى به اركانيسمهاى توليدكنندة ESBL هستند بايد آنتىبيوتيك مناسب بلهدق انتخاب شود. همجنين سويههايى كه حساسيت آنها در برابر
دكربوكسيلاز، آرزنين دهيدرولاز، توليد ايندول، تست سيترات،

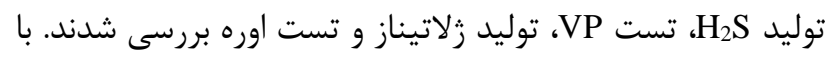

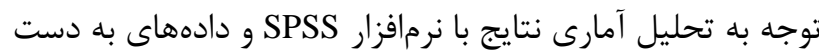

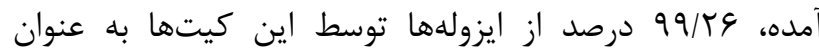

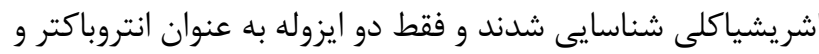

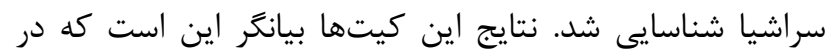
99/\% درصد موارد، نتايج مطابق با تستهاى بيوشيميايى ائى كلاسيك است.

نتايج مقاومت آنتى بيوتيكى در ايزولههاى جداسازىشده جدايهها از نظر ميزان حساسيت به آنتىبيوتيكهاى

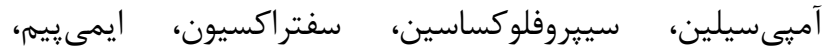
آميكاسين، سفيبيم، آزوترنام، سفوتاكسيم و سفتازيديم بررسى آنيى

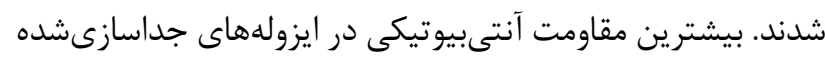

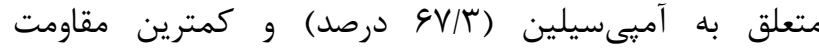

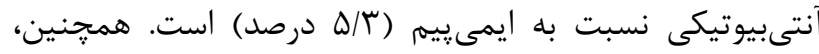

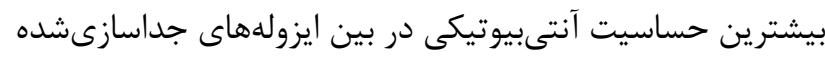

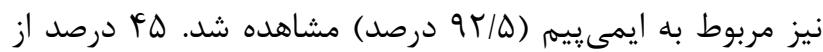

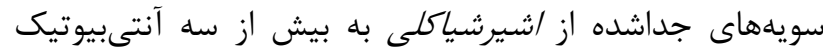

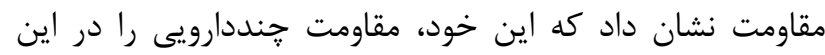

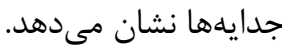

\section{شناسايى باكترىهاى توليدكنندة ESBL}

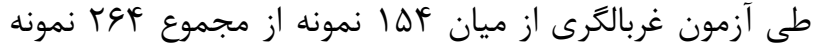

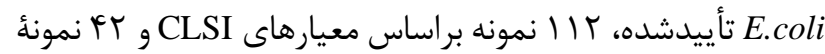
ديكر براساس مقاومت به كروههاى مختلف آنتىبيوتيكى انتخاب

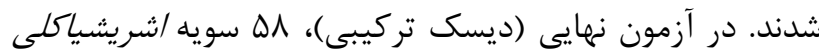

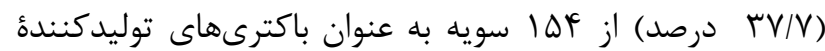

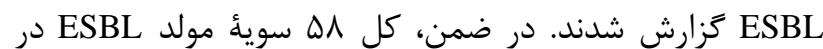
دستهاى كه طبق معيارهاى CLSI انتخاب شده بودند، قرار داشتند.

\section{شناسايى ثن}

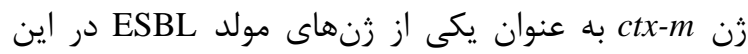

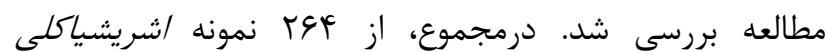

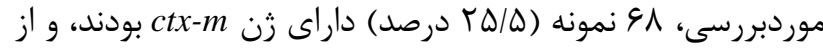

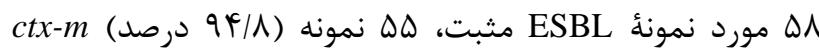

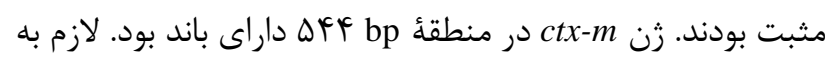

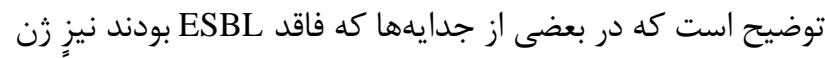
ctx-m شناسايى شد (شكل ()). 


$$
\text { بين نويسندكان تعارض منافع منافع گَزارش نشده است. }
$$

$$
\begin{aligned}
& \text { سفتازيديم، سفوتاكسيم و سفترياكسون كاهش يِدا كرده است بايد از } \\
& \text { نظرِ داشتنِ زنهاى ESBL بررسى شوند. }
\end{aligned}
$$

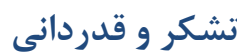

$$
\begin{aligned}
& \text { نويسندكان اين مقاله مراتب تشكر و قدردانى خود را از ز يرسنل }
\end{aligned}
$$

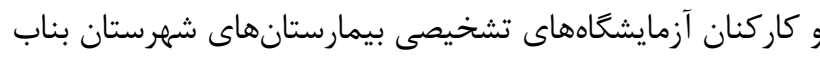

$$
\begin{aligned}
& \text { و آزمايشحاه ميكروبيولوزى داركنان ازمانشاه تشخيصى مراغه اعلام مى كنند. }
\end{aligned}
$$

\section{Reference}

1. Mahon C, Lehman D, Manuselis G. Textbook of Diagnostic Microbiology. Missourri: Elsevier; 2011.

2. Brooks GF, Jawetz E, Melnick JL, Adelberg EA. Jawetz, Melnick, and Adelberg's medical microbiology. New York: McGraw Hill Medical; 2010.

3. Murray PR. Medical microbiology. St. Louis: Mosby; 2002.

4. Tenover FC, Raney PM, Williams PP, Rasheed JK, Biddle JW, Oliver A, et al. Evaluation of the NCCLS extended-spectrum $\beta$-lactamase confirmation methods for Escherichia coli with isolates collected during Project ICARE. J Clin Microbiol. 2003; 41(7):3142-6. [DOI:10.1128/JCM.41.7.31423146.2003] [PMID] [PMCID]

5. Thomson KS. Controversies about extendedspectrum and AmpC beta-lactamases. Emerg Infect Dis. 2001; 7(2):333-6. [DOI:10.3201/eid0702.010238] [PMID] [PMCID]

6. 6 Soltan Dallal MM, Mobasseri G, Mehrabadi JF, Eshraghian M, Rastegar Lari A, Molla Aghamirzaei $\mathrm{H}$, Sabbaghi A, et al. Detection of CTX-M-1 beta lactamase gene in Escherichia coli isolated from clinical samples by Polymerase Chain Reaction (PCR). Tehran Univ Med J. 2011; 69(1):16-21.

7. Ling TK, Xiong J, Yu Y, Lee CC, Ye H, Hawkey PM. Multicenter antimicrobial susceptibility survey of gram-negative bacteria isolated from patients with community-acquired infections in the People's Republic of China. Antimicrob Agents Chemother. 2006; 50(1):374-8. [DOI:10.1128/AAC.50.1.374378.2006] [PMID] [PMCID]

8. Kiffer C, Hsiung A, Oplustil C, Sampaio J, Sakagami E, Turner P, et al. Antimicrobial susceptibility of Gram-negative bacteria in Brazilian hospitals: the MYSTIC Program Brazil 2003. Braz J Infecti Dis. 2005; 9(3):216-24. [DOI:10.1590/S1413$\underline{86702005000300004]}$ [PMID]
9. Mohajeri P, Izadi B, Rezai M, Falahi B, Khademi H, Ebrahimi R. Assessment of the frequency of extended spectrum beta lactamases producing Escherichia coli isolated from Urinary tract infections and its antibiotic resistance pattern in Kermanshah. J Ardabil Unive Med. 2011; 11(1):86-94. 10..

10.Dallal MM, Sabbaghi AY, Fallah JA, Aghamirzaei HM, Lari AR, Eshraghian MR, Sanei AF. Evaluation of presence of the bla-SHV and bla-AmpC (CITM, FOX) $\beta$-lactamase genes in clinical isolates of Escherichia coli. Journal of Medical Council of Islamic Republic of Iran. 2010;28(3).

11. Mantadakis E, Tsalkidis A, Panopoulou M, Pagkalis S, Tripsianis G, Falagas M, et al. Antimicrobial susceptibility of pediatric uropathogens in Thrace, Greece. Int urol Nephrol. 2011; 43(2):549-55. [DOI:10.1007/s11255-010-9797-5] [PMID]

12. Chong Y, Ito Y, Kamimura T. Genetic evolution and clinical impact in Extended-spectrum beta lactamaseproducing Escherichia coli and Klebsilla pneumoniae. infect Genet Evol. 2011; 11(7):1499-504. [DOI:10.1016/j.meegid.2011.06.001] [PMID]

13. Peirano G, Richardson D, Nigrin J, McGeer A, Loo V, Toye B, et al. High prevalence of ST131 isolates producing CTX-M-15 and CTX-M-14 among extended-spectrum- $\beta$-lactamase-producing Escherichia coli isolates from Canada. Antimicrob Agents Chemothe. 2010; 54(3):13927-30. [DOI:10.1128/AAC.01338-09] [PMID] [PMCID] 